\title{
Minor and major repairs of buildings and structures. The need to modernize the processes of planning and implementation. Requirements of current legislation of Russia
}

\author{
German Alekseev ${ }^{*}$, Evgenij Medvedev and Alexandra Bespalova \\ Moscow State University of Civil Engineering, Yaroslavskoe shosse, 26, Moscow, 129337, Russia
}

\begin{abstract}
Timely implementation of repair activities for buildings and structures, particularly of minor and major repairs underlie the safe operation of real estate and guarantee its long-term and effective use. Current requirements contained in Russian regulatory documents form the basis for the planning of maintenance activities' performing. The paper focuses on maintenance activities as part of the property management concept. The general ideas of minor and major repairs as integral measures at the stage of operation of buildings and structures are presented in the paper. All the necessary prescriptions for the maintenance of buildings and structures are formulated quite fully and clearly in terms of legislation. The basic principles of approaches to the repair activities' performing will remain the same for a long time. However, regularization of the procedural processes of operation, taking into account all the mechanisms that are available for today, is a matter of not only preserving and efficiently using capital construction objects, as well as maintaining their safety, but also information content of such technologically complex units, as buildings or structures under conditions of modern urban environment.
\end{abstract}

\section{Introduction}

The economic substantiation of decision making is obviously related to the correct assessment of operational and technical characteristics of a capital construction facility, while the choice of the proper strategy of activities directly impacts the aspects of safety.

It is worth mentioning that the present article examines the basic principles for determining the type of repair measures that are contained in the current regulatory documentation and do not concern the technical, economic or functional performance of real estate objects (minor or major repairs), however, the absence of such measures or their inappropriate planning can cause dangerous emergencies that may pose an instant danger to people's lives and the elimination of which requires significant financial investments. For this reason, the problems and methodological foundations of the survey of capital construction projects, as well as budgeting for building maintenance and engineering systems, are increasingly becoming the subject of researches $[1,3,5,7,9,10,13,14,15,16]$. It should be mentioned that

*Corresponding author: alexeev_german@bk.ru 
restoration works on cultural heritage sites with special status of use and maintenance are attributed to the implementation of special approach [11], which is regulated by special prescriptions $[18,24,25,26]$. The present article does not scrutinize such works.

\section{Repair activities as part of the property management concept}

Capital construction objects comprise the basis of any property complex. The planning and development of a program for the efficient use of buildings and structures is based on an assessment of their appropriate technical quality.

According to Article 55_25 of the Urban Planning Code of the Russian Federation (hereinafter referred to as the RF Urban Planning Code), an owner of a building or structure or a person (legal or physical) who owns the building on leasehold, economic management, operational management or other legal basis is responsible for the operation [17]. In addition, according to this Rule of the RF Civil Code (Clause 4), the frequency and composition of maintenance works to be performed, as well as maintaining the proper technical condition of buildings and structures, are governed by the requirements of project documentation or the results of monitoring the technical condition for each building or structure, proceeding from the conditions of their construction, reconstruction, major repairs or operation [17]. The statement "proceeding from the conditions of their construction, reconstruction, major repairs or operation" implies a system qualified approach to solving such type of problems, since it is the assessment of the conditions specified in the Urban Planning Code that should be performed at a high professional level.

The management element of the property complex, as of the basis for the main activity, is the program for the use of real estate objects, ensuring the effective functioning of these objects, including maintaining their operational and technical characteristics. The concept of such programs is laid down in the core part of the RF Urban Planning Code [17]. In particular, the 6th chapter refers to the requirements for the operation stage, while the general principles of open information control are formulated in the 7 th chapter.

In order to determine the strategy of planning and implementation of proper control over the management process, it is necessary to evaluate the real estate objects (buildings, structures) in terms of their appropriate technical quality. Based on the assessment, a list of works to be carried out is formed, and accordingly, the type of planned activities at the facilities are defined: maintenance, major repairs or restoration (for cultural heritage sites), which presents a system of dependent and interdependent activities conventionally shown in Figure 1. 


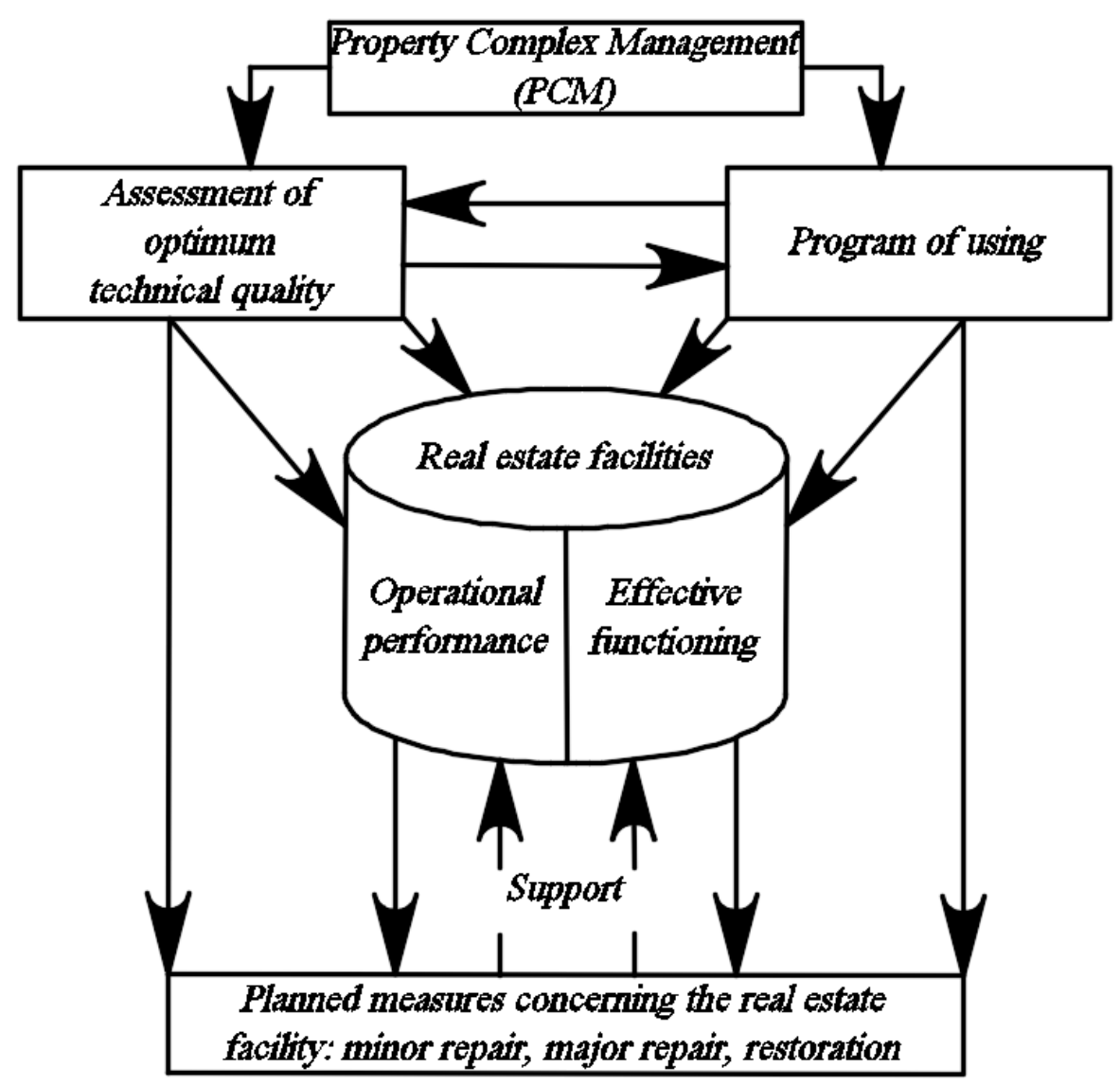

Fig. 1. Planning activities in the management of the property complex.

Maintenance (operational control) of buildings and structures should be carried out constantly by the technical service throughout the entire operation [17]. Maintenance and repairs are the basic system of measures, which should ensure the normal functioning of objects during the entire period of their use by designation.

On the basis of Clause 6 of Rule 55_24 of the RF Urban Planning Code [17], which contains the main requirements of the Russian legislation for the operation of buildings and structures and prescribes the following: "In order to ensure the safety of buildings and structures during their operation, maintenance of buildings, structures, operational control, and minor repairs of buildings and structures should be provided", the person responsible for the operation of a building must timely organize the implementation of activities on monitoring the technical condition of a building (structure), maintaining its efficiency and operability, also with the involvement of specialized organizations. At the same time, in accordance with clause 4.1 of Federal Standard GOST 31937-2011 [22], organizations equipped with modern instrumentation base and having highly qualified and experienced specialists are allowed to survey bearing structures of buildings. The above-mentioned Rule of the RF Urban Planning Code establishes the minimum mandatory composition of the section for activities on the operation of a facility. Special attention should be paid to the 
requirements contained in a project documentation of an object in terms of special requirements for monitoring the capital construction object (for example, the need for monitoring) within operation.

Whatever the reasons for incompleteness or lack of information (documentation) on construction objects (demanded information about their current state) are: change of owners, inevitable growth in the volume of real estate objects with a long service life, erection of buildings under permanently changing legislation, other circumstances [6],- the results will be mostly similar: it poses danger to safe operation and makes impossible the determination of the resource amount needed for further operation. In particular, some researchers distinguish the following reasons for a dramatic increase in deterioration of housing construction: breakdown of the system of preventive minor repairs for the housing facilities and limited financing of renovation processes [4]. Indeed, the absence of a systematic approach to meeting the requirements of current legislation, meanwhile necessary operating costs are known well, leads to the progressive increase in the amount of irreparable capital construction facilities.

The requirements in a number of standards existing in Russia have not been updated for quite a long time. In the general case, in accordance with BCN 58-88(r) (industry-specific building code) [17], when planning repair and construction works, the frequency of their performance can be chosen in accordance with the recommended minimum duration of effective operation of buildings and objects, as well as their structural elements. In the meantime, these requirements were elaborated 30 years ago, therefore the terms mentioned there are valid for structures of a corresponding age. Moreover, non-compliance with the basic requirements for performing minor and major repairs significantly reduces interrepair time of a building and dramatically affects its safety and maintenance indicators. The categories of technical condition of bearing structures of buildings and facilities, including the ground base, are assessed on the basis of the survey results and checking calculations, which are carried out in accordance with Federal Standard GOST 31937-2011 [22] depending on the type of an object. According to the assessment, structures, buildings and facilities, including a ground base, are divided into being:

- in a standards-compliant technical condition;

- in operable condition;

- $\quad$ in limited operable condition;

- in disrepair.

Today a technical survey is the only way to determine the strategy for the further existence of a building with a long service life, therefore the apparent need for such measures should become an undeniable reality for operating services. As for new construction projects, today documentation should obligatorily contain the section "Requirements for the safe operation of capital construction object", where the controlled parameters for the systems and materials of the new generation are recorded [9]. When comprehensive operating standards, the incompleteness of which is largely due to the high rates of technology development, are absent, it is critical to follow the design instructions and requirements for this section accurately.

At present, some questions concerning the rule-making in the area of building and structure maintenance are becoming the subject of discussion in the scientific community: "... in the field of rule-making, under consideration are the issues of building structures, utilities for capital construction projects of various functional purposes and structures in earthquake endangered zones, since there has no been operating standards until recent times. When it is necessary, the elaboration of rules is preceded by research that are conducted to obtain sufficient theoretical and reliable practical data to be considered when 
determining standardized parameters and specifying requirements for the operation of buildings and structures during preparation of regulatory, instructional, technical and organizational documentation."[8]. Researchers rightly draw attention to the necessity of training qualified specialists in the field of operation of capital construction facilities under modern conditions [5]. The mechanisms for the operational control of buildings and structures themselves cannot be fully formulated today because the existing tasks have to be solved within the framework of the available tools (visual inspection, technical inspection, repair activities). Meanwhile introducing new methods and approaches requires providing a significant platform for testing, the work on which should not harm the established control schemes and affect safety issues and operational performance of objects. Paragraphs 3 and 4 of the present article contain a brief drafting of the modern concepts of minor and major repairs.

\section{Minor repairs}

Minor repairs are always aimed at maintaining the performance of a building or structure; during minor repairs, small scale defects of finishing layers and fillings, as well as minor damages of utilities are eliminated. Minor repairs are carried out with a frequency that ensures the effective operation of a building from the moment when construction (or overhaul) is completed till the following major repairs.

Operational control is carried out by the person responsible for the operation of the building or structure (RF Urban Planning Code [17] (Clause 9, Art. 55_24), Clause 1, Article 40 No. 384-FL [20]). In the Russian Federation, the observance of the proper implementation of this type of control for objects of federal property is the responsibility of the management entity having the competence in managing state material reserve [18].

Minor repairs should be carried out at intervals that ensure the effective operation of a building or facility from the moment when its construction, reconstruction or major repairs are completed until it is put on for the next major repairs (reconstruction) (Figure 2).

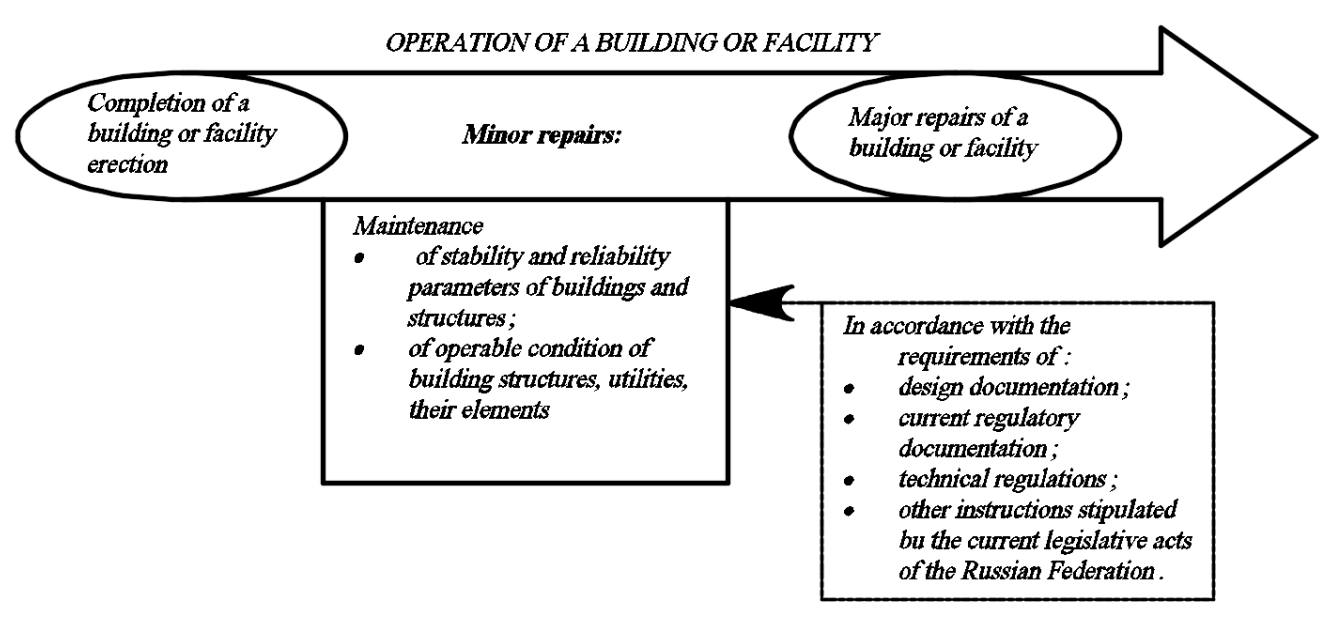

Fig. 2. Minor repairs. 
Since proceeding of minor repairs affects neither the parameters of building structure reliability, nor the project documentation development, nor initial permissive documentation, then special approvals for its implementation are not required.

It is worth mentioning that the significant scale of damage of finishing layers or fillings, numerous defects of utilities always indicate an increased intensity or degree of deterioration. Such attributes inevitably cause damage to the bearing structures and become a compelling reason for the comprehensive technical survey and planning of major repair activities. Elimination of attributes of deterioration concerning finishing layers and certain elements of utilities is unacceptable when there were not required repair works of structural elements, since it can hide the critical damage to supporting structures and utilities, which could later cause an accident and people's death.

\section{Major repairs}

In accordance with RF Urban Planning Code, major repairs are the replacement and (or) restoration of building structures or elements of such structures in capital construction objects (with the exception of load-bearing building structures), replacement and (or) restoration of engineering systems and utilities in capital construction objects or their elements, as well as the replacement of single elements of bearing structures with similar or other elements that improve indicators of such constructions, and (or) restoration of the specified elements [17].

For major repairs of various types of structures, there are terms recommended by regulatory documentation. One of the reasons for a decision on major repairs may also be the actual unsatisfactory condition of an object: manifested signs of physical deterioration, significant defects in bearing or enclosing structures, of utilities. In this case, the cause of early failure of structural elements may be a violation of the conditions of normal operation of buildings, including the lack of minor repair measures.

In terms of the legislation of the Russian Federation, comprehensive major repairs are a serious construction activity requiring a comprehensive assessment of technical condition of a facility and the elaboration of design-estimate documentation, initial permissive documentation, and involvement of competent organizations (SRO in the territory of Russia). It is important when planning major repairs to provide maximally the required repair measures for the object in order to avoid failures and emergencies after the completion of construction and installation works during further operation.

\section{Strategy of planning repair activities under current conditions}

When elaborating modern sets of operation rules, one may focus on the criteria of organizational and technological reliability, as some researchers assume [9]. This is an integrated approach, designed to take into account many factors of influence, particularly on the process of building operation.

Under conditions of the increasing use of BIM (Building Informational Model) technologies, the automation of the facility management process is quite applicable as a combination of the concept of asset management: EAM (Enterprise Asset Management) and BIM. The first one contains all the tools for organizing the operational maintenance of assets and making decisions on appropriate operation way and on minor and major repairs, while the second one has a detailed structured information model that takes into account the interrelations of various information layers [2]. 
It is clear that the absolute proven and widely accepted methodology for the operation of capital construction facilities in modern conditions with the most effective use of modern technologies can be discussed only after some accumulative methods of control and decision-making are implemented. The ideological promotion in this direction is supported at the legislative level, however, there is an urgent need to test new approaches to the issues of building and structure maintenance in real conditions by specialists of the appropriate profile.

\section{Conclusions}

In terms of legislation, all the necessary prescriptions regarding the maintenance of buildings and structures are formulated quite fully and clearly. The general principles of approaches to repair activities will remain the same for a long time. However, regularization of the procedural processes of operation, taking into account all the mechanisms that are available for today, is a matter of not only preserving and efficiently using capital construction objects, as well as their safety, but also information content of such technologically complex units, as buildings or structures under conditions of modern urban environment. At the same time, it is necessary to train appropriate specialists who will be able to solve operational control problems at the modern level. Technically, "elder" capital construction facilities have a set of procedural processes of operation that differs from the one of new construction facilities, but the general principle of mandatory control should be implemented ubiquitously. The latest information technologies used by engineers should become an effective tool for ensuring the safety and security of buildings and structures. The situations when owners of real estate objects and legal entities exercising the rights of owners do not have an idea about the operation assurance and technical condition of their objects should be excluded.

\section{References}

1. Gordin I.A., Tolstyh Y.O., Lyulkina N.M. 2014 Analiz opyta formirovaniya i realizacii regionalnyh programm kapitalnogo remonta $v$ regionah $R F$ Sovremennye problemy nauki i obrazovaniya. № 6. S. 425.

2. Ushanov A.A., Borodin V.A., Spanderashvili D.V. 2016 Primenenie informacionnyh modelej v ehkspluatacii zdanij $i$ sooruzhenij Reshenie problem razvitiya predpriyatij: rol nauchnyh issledovanij № 10. S. 6

3. Dementeva M.E., Dementeva A.V 2018 Vozmozhnosti primeneniya BIM-tekhnologij pri razrabotke ehkspluatacionnyh programm BST: Byulleten stroitelnoj tekhniki. № 8 (1008). S. 43-45

4. Kivilev V.V. 2018 Renovaciya zhilishchnogo fonda: vosstanovlenie ehkspluatacionnyh harakteristik zhilyh zdanij Vestnik Tomskogo gosudarstvennogo arhitekturnostroitel'nogo universiteta. 2018. T. 20. № 3. S. 120-132.

5. Korol E.A., 2017 Metodologiya formirovaniya normativnoj bazy $v$ oblasti ehkspluatacii zdanij $i$ sooruzhenij $i$ modernizaciya obrazovatelnyh programm Integraciya, partnerstvo $i$ innovacii $v$ stroitelnoj nauke $i$ obrazovanii, Sbornik materialov mezhdunarodnoj nauchnoj konferencii. FGBOU VO «Nacionalnyj issledovatelskij Moskovskij gosudarstvennyj stroitelnyj universitet». S. 834-838.

6. Korotkov D.YU., Chulkov V.O. Zhiznennyj cikl stroitel'nogo obekta 2013 Mir nauki. № 1. S. 18. 
7. Lomtev I.A. 2017 Ehtapy i problemy pri obsledovanii zhilyh zdanij i sooruzhenij

Nauka i innovacii v stroitelstve (k 45-letiyu kafedry stroitel'stva i gorodskogo hozyajstva): sbornik dokladov Mezhdunarodnoj nauchno-prakticheskoj konferencii. Belgorodskij gosudarstvennyj tekhnologicheskij universitet im. V.G. Shuhova. S. 1824.

8. Mamin A.N., Kodysh E.N., Bobrov V.V. 2018 Razrabotka normativnoj dokumentacii v oblasti ehkspluatacii zdanij i sooruzhenij Promyshlennoe i grazhdanskoe stroitel'stvo. № 6. S. 24-27.

9. Mohov A.I., Murzin D.V., Borovoj E.A., Tabakov S.A. 2016 Resursy ehffektivnosti funkcionirovaniya zdanij, sooruzhenij pri kompleksnom podhode $k$ ih ehkspluatacii Othody i resursy. T. 3. № 3. S. 5

10. Pastushkov P.P., Grinfel'd G.I., Pavlenko N.V., Bespalov A.E., Korkina E.V. 2015 Raschetnoe opredelenie ehkspluatacionnoj vlazhnosti avtoklavnogo gazobetona $v$ razlichnyh klimaticheskih zonah stroitelstva Vestnik MGSU. № 2. S. 60-69.

11. Paushkin A.G., Cherkasova L.I., Ivanov M.N. 2014 O sistemnyh kriteriyah opredeleniya kategorij tekhnicheskogo sostoyaniya obektov kulturnogo naslediya po stepeni iznosa i povrezhdeniya Internet-Vestnik VolgGASU.. № 4 (35). S. 19.

12. Chulkov G.O., Korotkov D.YU., Malceva A.L. 2017 Struktura zhiznennogo cikla obekta ili processa kak dorozhnaya karta ego funkcionirovaniya Nauka i tekhnologii: aktualnye voprosy, dostizheniya, innovacii Sbornik dokladov i materialov Nacionalnoj nauchno-prakticheskoj konferencii S. 154-164.

13. Giel, B. and Issa, R.R.A., 2013 Return On Investment Analysis of Using Building Information Modeling in Construction Journal of Computing in Civil Engineering, ASCE, 27 (5), pp 511-521

14. Bossman J.H. 2015 Kalkulationsverfahren zur Instandshaltungbudgetierung Gebäudetechnischer anlagen öffentlicher Immobilienportfolien Karlsruhe, Karlsruher Institut für Technologie, der Fakultät für Bauingenieur-, Geo- und UmweltwissenschaftenDissertation

15. Klingbereger J. 2007 Ein Beitrag zur systematischen Instandhaltung von Gebäuden Darmstadt, Technische Universität, Fachbereich Bauingenieurwesen und Geodäsie, Dissertation

16. Staniaszek D., Kunkel S., Shnapp S. 2015 Renovation in practice. Best practice examples of voluntary and mandatory initiatives across Europe Buildings Performance Institute Europe (BPIE) $52 \mathrm{p}$.

17. №190-FZ ot 29.12.2004 g. Federalnyj zakon «Gradostroitelnyj kodeks Rossijskoj federacii» (red. Dejstvuet s 14.08.2018) http://kodeks.ru

18. №73-FZ ot 25.06.2002 g. Federalnyj zakon «Ob obektah kul'turnogo naslediya (pamyatnikah istorii $i$ kultury) narodov Rossijskoj Federacii (s izmeneniyami na 03 avgusta 2018 g.)» http://kodeks.ru

19. Postanovlenie Pravitelstva RF ot 15.04.2014 №327 «Ob utverzhdenii gosudarstvennoj programmy "Upravlenie federalnym imushchestvom» (s izmeneniyami na 30 marta $2018 \mathrm{~g}$.).

20. №384-FZ ot 30.12.2009 g. Federalnyj zakon «Tekhnicheskij reglament o bezopasnosti zdanij $i$ sooruzhenij» http://kodeks.ru

21. SP 255.1325800.2016 Buildings and structures. Operating rules. General provisions.

22. GOST 31937-2011; Buildings and constructions. Rules of inspection and monitoring of the technical condition http://kodeks.ru

23. VSN 58-88(p) Regulations on the organization and conduct of reconstruction, repair and maintenance of buildings, public facilities and socio-cultural purposes http://kodeks.mgsu.ru 
24. GOST 55528-2013 Composition and content of scientific and project documentation for the conservation of cultural heritage. Monuments of history and culture. General requirements http://kodeks.ru

25. GOST $R$ 5567-2013; The order of the organization and conducting technical engineering studies on researches on objects of cultural heritage Monuments of history and culture. General requirements http://kodeks.ru

26. GOST R 56198-2014 Monitoring of technical state of the cultural heritage objects. Immovable monuments. General requirements http://kodeks.ru 